\title{
Students' perception on the use of the visual learning aid: wh-word hand in the efl classroom.
}

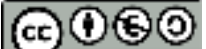
Students' perception on the use of the visual learning aid: wh-word hand in the EFL classroom.

Elsa de los Ángeles Hernández Chérrez. ${ }^{1}$ \& Nelly Patricia Galora Moya. ${ }^{2}$

\author{
Recibido: 02-09-2017 / Revisado 05-11-2017 Aceptado: 10-12-2017/ Publicado: 01-01-2018
}

\begin{abstract}
.
DOI: https://doi.org/10.33262/cienciadigital.v2i1.31

This study aims to investigate students' perceptions on the use of the visual learning aid: wh-word hand as a visual tool for enhancing students' content learning, class participation and understanding. To achieve the aim of the study, the mixed-method approach was used to collect the required data with the help of 91 students from the A1 and A2 levels of English at the Languages Center - Universidad Técnica de Ambato, Ecuador. All the participants completed an online survey and the data gathered was tabulated and interpreted descriptively. The findings show various results from the questionnaire answered by students under these 4 headings: perceived ease of use, perceived usefulness, perceived attitude towards usage, and perceived intentional behavior to use. The analysis of the data indicated that the majority of students had positive perceptions on the use of wh-question word hand as a visual learning aid in the EFL classroom.
\end{abstract}

Keywords: Active Learning, Cognitive Process, Interaction, Questioning Visual Learning Aids.

\section{Resumen.}

Este estudio tiene como objetivo investigar las percepciones de los estudiantes sobre el uso de la ayuda visual: wh-word hand como una herramienta visual para mejorar el aprendizaje del contenido, participación y comprensión de clase. Para lograr el objetivo del estudio, se utilizó el enfoque de método mixto para recopilar los datos

1 Universidad Técnica de Ambato, Centro de Idiomas, Ambato, Ecuador, eda.hernandez@uta.edu.ec

2 Universidad Técnica de Ambato, Centro de Idiomas, Ambato, Ecuador, np.galora@uta.edu.ec 
requeridos con la colaboración de 91 estudiantes de los niveles A1 y A2 de inglés en el Centro de Idiomas - Universidad Técnica de Ambato, Ecuador. Todos los participantes completaron una encuesta en línea y la información recopilada se tabuló e interpretó descriptivamente. Los hallazgos muestran varios resultados del cuestionario contestado por los estudiantes bajo estos 4 títulos: facilidad de uso percibida, utilidad percibida, actitud percibida hacia el uso y comportamiento intencional de usar percibido. El análisis de los datos indicó que la mayoría de los estudiantes tenía una percepción positiva del uso de wh-question word hand como una ayuda visual de aprendizaje en el aula de EFL.

Palabras Claves: Aprendizaje Activo, Proceso Cognitivo, Interacción, Ayudas Visuales de Aprendizaje para Formular Preguntas

\section{Introduction.}

Teaching English in a country where its population learn it as a Foreign Language, has turned to be an issue of major concern for English teachers in Ecuador. Although, English has long been taught in all educational settings: kindergarten, elementary school, high school and higher education and English teachers work hard to meet students' real needs, it is quite difficult to meet students' learning styles. Therefore, language teachers usually use visual materials in their lessons to try to make teaching more effective. Studies have concluded that students can learn abstract or difficult concepts easily through the use of visual aids such as images, pictures, drawings, colors, among others. According to Merriam-Webster Dictionary, a visual aid is a teaching device that makes language easier to understand. Talking about students who start learning a foreign language, they encounter various difficulties during the teaching and learning process. For instance, teachers who have been working with students from A1 and A2 English levels for a long time claim that these groups of students struggle making and answering Wh questions. Consequently, students do not take an active participation neither in class, nor in reading or pair work discussion activities. Simply, they do not actually know how wh-question words work and how to formulate a Wh question.

Therefore, it is important to focus the teaching process on students' learning styles and present content using visual elements like graphs, images, pictures or drawings to foster learning. This way, students who are visual learners are able to recall information more easily. In addition, visual aids can be used to make the learning experience more real, more accurate and more active. Implementing visual learning aids on teaching has proved to achieve effective learning outcomes. For instance, McDaniel, M. A., \& Einstein, G. O., (1986) say visuals can transform abstract and difficult concepts into more tangible and 
welcoming ones, as well as permit that learning becomes much more effective and long lasting. Kouyoumdjian, (2012) states in his web site that the brain takes some more time to retain words, whereas visuals are concrete and easier to remember.

Thus, educators are meant to use visual aids such as photos, illustrations, icons, symbols, sketches, figures, concept maps and wh question cue cards, among others. West, M (2011) said in her 8-minute talk that schools concluded that 50 or $60 \%$ of students who were tested as picture thinkers have average to below average learning.

Hence, students usually have a hard time remembering words by repetition and they cannot recall words easily. However, students start learning and understanding the meaning from those words if teachers give them the opportunity to see learning through visual aids. She also added that students start making associations if they actually see what to associate. Kouyoumdjian, (2012) highlights the great benefits of learning through visuals, its use can facilitate learning in a shorter time, improve comprehension, enhance retrieval, and increase retention. The implementation of visual materials makes teaching much clearer and it also helps students retain more information. Carney, R. N., Levin, M. E., \& Levin, J. R. , (1993).

The objective of this study is to examine A1 English learners' perceptions with regard to the use of visual aids in the EFL classroom. More specifically, the study addresses the following research questions:

1) What is the students' perceptions on implementing visual aids in English teaching?

2) ¿Are there any significant differences in learners' perceptions with the implementation of "wh-question hand" visual aid?

3) ¿Are there any significant differences between the learners' and their teachers' perceptions on the implementation of visual aids?

To find answers to these questions, we used data collected from class observations where we used an observation checklist, interviews and an online survey with a qualitative ethnographic approach which allows for description, theory-building and comparison. Chaudron, (1988).

\section{Visual Learning.}

There are different learning styles in which students receive information. Three of the most popular ones are visual, auditory, and kinesthetic. In order to help students learn, teachers need to teach as many of these preferences as possible and incorporate activities for all 
these learning styles in their curriculum activities so that students are able to succeed in their classes.

Visual learners learn visually by means of charts, graphs, and pictures. Auditory learners learn by listening to lectures and reading. Kinesthetic learners learn by doing. CelciaMurcia (2001) defines learning styles as the general approaches, for example, global or analytic, auditory or visual, that students use in acquiring a new language or in learning any other subject.

It is a well-known fact that visual materials are a great help in stimulating and facilitating the learning of a foreign language. Visual learners think in pictures and learn best in visual images. They depend on the instructor's or facilitator's non-verbal cues such as body language to help with understanding. Sometimes, visual learners favor sitting in the front of the classroom. They also take descriptive notes over the material being presented (Abbas, 2012).

According to Jamal (2016), visual learning also helps students to develop visual thinking, which is a learning style whereby the learner comes to understand better and retain information better by associating ideas, words and concepts with images. Research tells us that the majority of students in a regular classroom need to see information in order to learn it. Some common visual learning strategies include creating graphic organizers, diagramming, mind mapping, outlining and more. In this way students see how ideas are connected and realize how information can be grouped and organized (Abbas, 2012).

Various studies report that $75 \%$ of all information processed by the brain is derived from visual formats. Furthermore, visual information is mapped better in students' minds (Williams, 2009). Based on various studies, students remember information better when it is represented both visually and verbally. According to Williams (2009), many media and many styles of visual presentation are useful to the language learner. That is to say, all visual materials have positive contributions to language learning as long as they are used at the right time, in the right place.

Dunn and Dunn (1978), say that teachers should try to make changes in their classrooms which will be beneficial to every learning style. Some of these changes include room redesign, the development of small-group techniques, and the development of Contract Activity Packages. Redesigning the classroom involves locating dividers that can be used to arrange the room creatively, clearing the floor area, and incorporating student thoughts and ideas into the design of the classroom. Small-group techniques often include a "circle of knowledge" in which students sit in a circle and discuss a subject collaboratively as well as other techniques such as team learning and brainstorming. Contract Activity Packages are educational plans that facilitate learning by using the following elements: 1) clear statement 
of what the students needs to learn; 2) multisensory resources (auditory, visual, tactile, kinesthetic) that teach the required information; 3) activities through which the newlymastered information can be used creatively; 4) the sharing of creative projects within small groups of classmates; 5) at least 3 small-group techniques; 6) a pre-test, a self-test, and a post-test.

In this study we introduce a meaningful learning strategy for the classroom that promotes the presentation of information in a visual format which is the "wh-word hand" in order to help students to better manage learning objectives and achieve academic success.

\section{The Ecuadorian Context.}

Students from Starter A1 level at the Languages Center-Universidad Técnica de Ambato struggle to make questions. It is difficult for most English learners to read or understand

spoken English. Teachers observed that students have difficulty making or answering Whquestions when speaking or reading in English. Furthermore, students do not answer teachers' questions because they have difficulty processing auditory information and they tend to ask their peers for translation. Therefore, visual learning may facilitate students' understanding and learning. This study wanted to examine whether the use of visual learning aids enhances students' class participation, as well as if it contributes on the development of EFL students' reading comprehension and speaking skills at the Languages Center at Universidad Técnica de Ambato.

The visual learning aid called "Wh-question word hand" has been used in this research at the Languages Center - Universidad Técnica de Ambato. This technique has been used during the semester October 2017-February 2018 with EFL students of levels A1 and A2. The current study has evaluated the use of the "wh-question Word hand" visual aid from the students' perception and it has the following considerations:

- The findings of this study would also give a clearer idea of how to deal with students' problems when asking or answering questions.

- It will help to clarify difficult concepts, as well as motivate and enhance learning. Furthermore, it will contribute with the solution to the problem of students who are not table to make or answer a Wh-question.

- Lastly, "Wh-question hand" and "wh cue cards" that were modified and adapted to Spanish speakers may be reused in future research with other educational contexts. 


\section{Methodology.}

\section{How the visual aid wh-word hand was applied in the EFL classroom}

Once we started the new semester October 2017-. February 2018, all students were asked to investigate the meaning and uses of the following wh- question words: what, who, when, where, why, how, how often, how old, how long and which. The second week, students chose 10 poster board sheets in different colors and wrote one wh-word on them. They drew the meaning or pasted a picture in front of the card. Then, each week students studied and practiced using two wh -question words. They wrote questions on the back of the cards. Then, once a week, they practiced asking and answering questions to each other. First, they tried looking at the cards, but later, they did not need to see them.

Picture 1

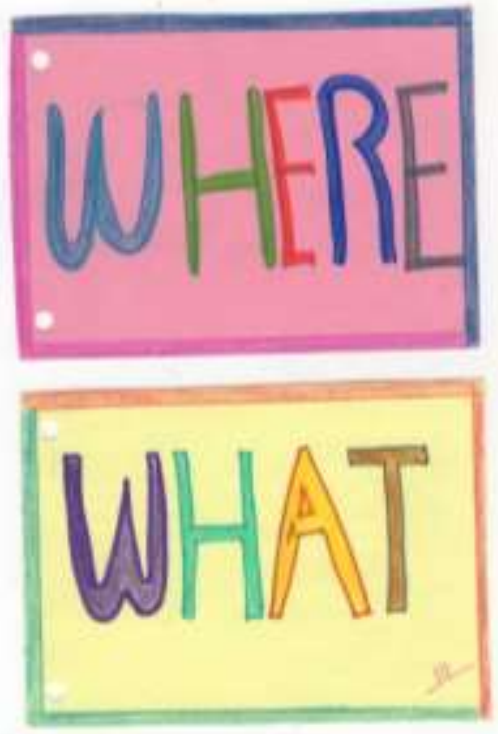

Flascards: Wh- question words
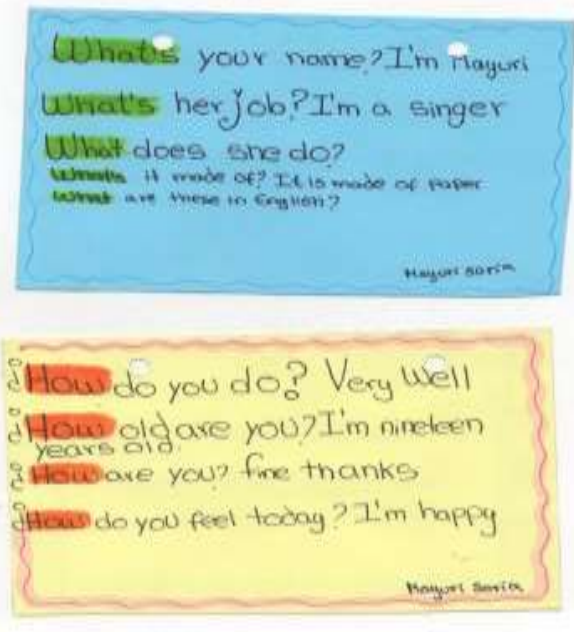

Sources: Students' visual materials

By: Mayuri Soria, A1 ESL student

Instructors presented the visual aid "wh-word hand" to the whole class. Students drew a hand and wrote the following question element on each finger: 1) Wh, 2) Auxiliary, 3) Subject, 4) Verb, and 5? Complement and the question mark (?). When students studied 
tenses like Present, Past and Future, all students made their wh-question hand. They practiced using this visual material for reading and speaking tasks (interviews, discussions dance table tasks). After some time, students became autonomous learners. They did not depend on the visual aid anymore. They used their real hand and practiced questioning each other. They put together their both hands and moved their fingers every time they were asked to formulate a question, using the question element. Some students did it faster. For others it took some more time; but at the end of this long process they finally learned to make questions in English.

Making and answering questions is usually omitted or not practiced a lot in the EFL class because questioning is not that easy, but it is worth practicing because it is one way to start communicating in a foreign language.

Picture 2 Wh-word hand
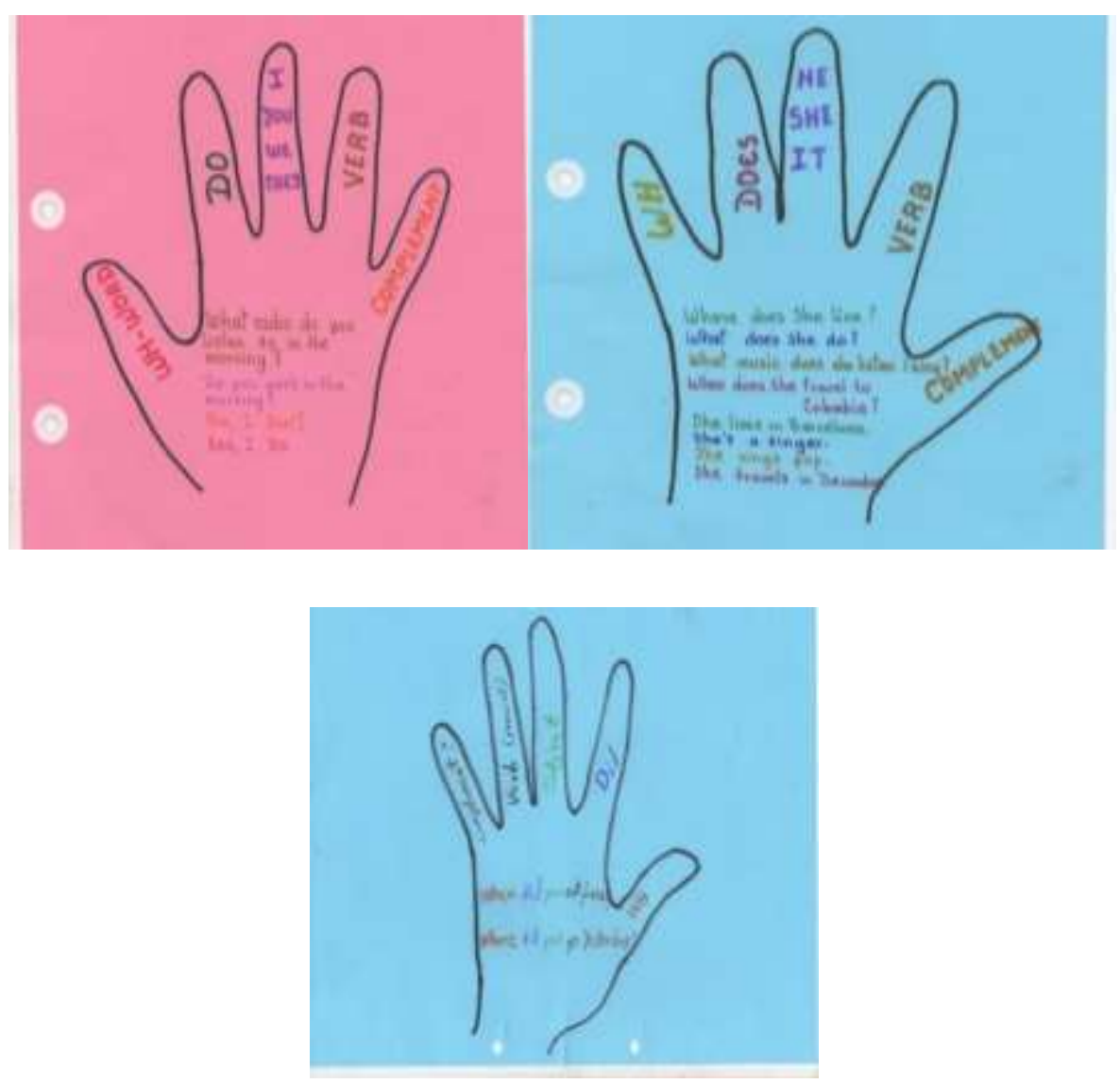

Sources: Students' visual materials

By: Silvana Bustillos A1 ESL student 


\section{Participants.}

\section{Students.}

- There were a total of 91 students, 60 female and 31 male students, all undergraduates. The students were enrolled in the academic year 2017-2018. The sample was taken from Universidad Técnica de Ambato at the Languages Center. Students were enrolled in different faculties such as: Food engineering, Mechanical Engineering, Human Sciences and Education, Law, Economics, and Administration.

\section{Instructors.}

- The instructors sample included 2 English teachers who work at Languages Center. One teacher taught A1 English level (Starter) and the other teacher taught A2 English level (Elementary). Their age was between 40-45 years and their teaching experience at Higher Education ranged from 15- to 18 years. One of the two professors has a PhD degree and the other is a Master holder in English Language Teaching.

\section{The questionnaire.}

The questionnaire used in this study was a modified version of the one used by the authors Wiyaka, Januarious Mujiyanto \& Dwi Rukimi on their study called "Students Perception on the usefulness of ICT-Base Language Program".

To ensure the appropriateness and comprehensibility of the questionnaire items, the researchers consulted three other English teachers who were teaching both Starter and Elementary English levels. The first questionnaire for the students was written in English and later piloted; but there were some problems about the new terms. So, it was modified and written on students' native language (Spanish) to ensure they understood all the items.

As shown in Table 1, there are five items measured in accordance to the current study research model. The measured items include: perceived ease of use (1 item), perceived usefulness ( 2 items), attitude toward usage ( 1 items), and behavioral intention to use (1 item). Wiyaka, Januarius Mujiyanto, Dwi Rukmini.(2018). 
Table 1. Questionnaire.

\begin{tabular}{ll}
\hline SECTION & THE MEASURED ITEMS \\
Section I & $\begin{array}{l}\text { Perceived Ease of Use } \\
\text { I feel that it would be helpful to use the visual aid (wh-word hand) to become skillful at } \\
\text { making questions in English in different tenses. } \\
\text { Usefulness }\end{array}$ \\
Section II & $\begin{array}{l}\text { I feel that the visual aid (wh-word hand) would enable to develop questioning skills in } \\
\text { English } \\
\text { Attitude Toward Usage }\end{array}$ \\
& $\begin{array}{l}\text { I feel that the visual aid (wh-word hand) is a great idea that could be used in the EFL } \\
\text { teaching. } \\
\text { Section III feel that the visual aid (wh-word hand) is an attractive visual learning aid that we can use } \\
\text { to develop the four English skills. } \\
\text { Behavioral Intention to Use }\end{array}$ \\
Section IV $\quad$\begin{tabular}{l} 
I plan to use the visual aid (wh-word hand) in the future with the next English levels. \\
\hline
\end{tabular}
\end{tabular}

By: Research Group.

The items were ranked on a Likert Scale (cLeod, 2008) which suggests ranging from 1 (least important) to 5 (most important). The survey was made on Gmail and its link was distributed to the students via email or WhatsApp. The use of this technology was helpful because $100 \%$ of students completed the survey on line.

The questionnaire for the English teachers was slightly different from students' questionnaire. It was distributed on paper to each English teacher who completed it immediately and gave it back to the researchers to be analyzed.

\section{Data analysis.}

\section{Results.}

The following results are presented in relation to the research questions and the students ${ }^{\prime}$ on line survey from A1 (starter) and A2 (Elementary) level at the Languages CenterUniversidad Técnica de Ambato. We talked about students' perceptions of the visual aid wh-word hand in the teaching and learning process. Then, we also explored English teachers' perceptions about visual aids in the EFL class. Following the results of how the visual aid (wh-word hand) implemented was used at the Languages Center - Universidad Técnica de Ambato. 
a) Students' perceptions of the visual aid wh-word hand

b) Instructors' perceptions of the visual aid wh-word hand

Descriptive statistics was used to examine data obtained in the online survey. The descriptive statistics method allowed to do quantitative analysis of data which was summarized with graphics analysis, using as a reference the information foun at Web Center for Social Research Methods, (2017). This study used the method of descriptive statistics in terms of percentage to process data and to analyze and interpret data, researchers employed the method of deduction.

This study aimed to find out how students perceived ease of use, in terms of the degree of effort they made applying the visual aid "wh-word hand". The following table presents the students' responses.

Table 2. Section I, Perceived Ease of Use.

\begin{tabular}{|c|c|c|c|c|c|c|}
\hline No Item & $\begin{array}{l}\text { Strongly } \\
\text { agree }\end{array}$ & Agree & Neutral & Disagree & $\begin{array}{l}\text { Strongly } \\
\text { disagree }\end{array}$ & Total \\
\hline $\begin{array}{l}\text { I feel that it would be helpful to use } \\
\text { the visual aid( wh-word hand) to } \\
\text { become skillful at making questions } \\
\text { in English in different tenses. }\end{array}$ & 59 & 29 & 2 & & 1 & 91 \\
\hline Total & 59 & 29 & 2 & & 1 & 91 \\
\hline Percentage & $64,80 \%$ & $32,20 \%$ & $2 \%$ & & $1 \%$ & $100 \%$ \\
\hline
\end{tabular}

\section{By: Research Group}

From the above table we can infer that 88 out of 91 students agreed that using the visual aid wh-word hand is easy to use. There is only $1 \%$ of students who perceived that the visual aid is not easy to use. From the table we can also infer that $2 \%$ of the respondents' answer was neutral. It is important to consider practicality and simplicity of the visual aid, since students belong to a low English level. The instructors or teachers who worked in this study claim to have implemented new materials or ideas that were free from difficulty or great effort. 
Table 3. Section II, Usefulness.

\begin{tabular}{|c|c|c|c|c|c|c|}
\hline No Item & $\begin{array}{l}\text { Strongly } \\
\text { agree }\end{array}$ & agree & Neutral & Disagree & $\begin{array}{l}\text { Strongly } \\
\text { disagree }\end{array}$ & Total \\
\hline $\begin{array}{l}\text { I feel that the visual aid ( wh-word } \\
\text { hand) would ennable to develop } \\
\text { questionning skill in English. }\end{array}$ & 57 & 28 & 5 & & 1 & 91 \\
\hline Total & $5700,00 \%$ & $2800,00 \%$ & $500 \%$ & & $100 \%$ & $9100 \%$ \\
\hline Percentage & $62.6 \%$ & $\mathbf{3 0 . 8 \%}$ & $5,60 \%$ & & $1 \%$ & $100 \%$ \\
\hline
\end{tabular}

\section{By: Research Group.}

It is clear from the table above that 85 students perceived that the visual wh-word hand is useful to develop questioning skills in English. 1\% of respondents thought that this visual aid would not be useful to develop questioning skills. Only 5,6\% of students could not decide between agreeing and disagreeing that the visual aid could help to improve making questions in English. In other words, students will use the visual aid when it is useful for their everyday learning.

Table 4. Section III, Attitude Toward Usage.

\begin{tabular}{|c|c|c|c|c|c|c|}
\hline No Item & $\begin{array}{c}\text { Strongly } \\
\text { agree }\end{array}$ & agree & Neutral & Disagree & $\begin{array}{l}\text { Strongly } \\
\text { disagree }\end{array}$ & Total \\
\hline $\begin{array}{l}\text { I feel that the visual aid (wh- } \\
\text { word hand) is a great idea that } \\
\text { could be used in the EFL } \\
\text { teaching. }\end{array}$ & 61 & 26 & 3 & & 1 & 91 \\
\hline Total & $6100,00 \%$ & $2600,00 \%$ & $300 \%$ & & $100 \%$ & $9100 \%$ \\
\hline Percentage & $67 \%$ & $28.5 \%$ & $3.5 \%$ & & $1 \%$ & $100 \%$ \\
\hline
\end{tabular}

\section{By: Research Group}

87 out of 91 of students have a positive attitude towards the usage of the visual aid (whword hand) while 3,5\% do not have ideas about it and $1 \%$ have a negative attitude of using it in their classroom. 
Table 5. Section III, Attitude Toward Usage

\begin{tabular}{lccccc}
\hline \multicolumn{1}{c}{ No Item } & $\begin{array}{c}\text { Strongly } \\
\text { agree }\end{array}$ & agree & Neutral & $\begin{array}{c}\text { Disagree } \\
\text { Strongly } \\
\text { disagree }\end{array}$ & Total \\
\hline $\begin{array}{l}\text { I feel that the visual aid ( wh- } \\
\text { word hand) is an attractive }\end{array}$ & & & & & \\
$\begin{array}{l}\text { visual learning aid that we can } \\
\text { use to develop the four english } \\
\text { skills. }\end{array}$ & & 36 & 2 & 3 & 91 \\
Total & $\mathbf{5 0}$ & $\mathbf{3 6}$ & $\mathbf{2}$ & & \\
& & & & & \\
\end{tabular}

\section{By: Research Group}

It can be identified from the table that 86 out of 91 students have a positive attitude towards the usage of the visual learning aid to develop the 4 English skills. Three participants have a negative attitude and 2 were not sure about the answer. Students' attitude is important because it guides future use of the visual material in the EFL classroom.

Table 6. Section IV, Behavioral Intention to Use

\begin{tabular}{|c|c|c|c|c|c|c|}
\hline No Item & $\begin{array}{c}\text { Strongly } \\
\text { agree }\end{array}$ & agree & Neutral & Disagree & $\begin{array}{l}\text { Strongly } \\
\text { disagree }\end{array}$ & Total \\
\hline $\begin{array}{l}\text { I plan to use the visual aid (wh-word } \\
\text { hand) in the future in the next english } \\
\text { levels. }\end{array}$ & 51 & 27 & 11 & & 2 & 91 \\
\hline Total & $5100,00 \%$ & $2700,00 \%$ & $1100 \%$ & & $200 \%$ & $9100 \%$ \\
\hline Percentage & $55,90 \%$ & $30 \%$ & $12,10 \%$ & & $2 \%$ & $100 \%$ \\
\hline
\end{tabular}

\section{By: Research Group}

It can be inferred from the table that $85,9 \%$ of the students who strongly agree and those in the group of agree plan to use the visual aid wh-word hand in the next English levels, while $12.1 \%$ have not decided yet, and $2 \%$ do not intend to use this visual aid.

\section{Conclusions.}

The findings have demonstrated that students' perceptions towards using the visual aid whword hand in their EFL classroom was positive. The result of the survey can be summarized as follows:

1) The results indicate positive perception on the ease of use of visual aids. $88 \%$ of students perceived that the material used to learn how to make questions was effective and enabled 
them to develop questioning skills in English. There is only $1 \%$ of the students who found this visual aid quite difficult to use. This shows the visual material used can facilitate learning and better understanding

a) Low achievers' perceptions about the visual aid (wh-word question)

The survey results show that students had a positive perception of the material used in the class. Students who could not understand, write and answer questions perceived this material as useful to develop questioning skills, as well as the four English skills. They also expressed their willingness to use this visual material within the next English levels because this learning aid facilitates better understanding and foster their learning.

Teachers observed that their students enjoyed looking at the visual wh-word hand and also used it to learn how to make question. Furthermore, with the visual aid, low achievers were motivated and took shorter time to write questions to be used in peer discussion, reading lessons, or in two line-talking activities. They felt happy because they learned and challenged themselves to go beyond. At the beginning they were dependent on this material but later on, they behaved as autonomous learners. They did not need to use the visual aid anymore, they just looked at every finger from their right hand to remember how to make questions. They actually made questions in present, past, and even in future. These students appreciated having this great visual learning aid in their learning process. Finally, $78 \%$ of the students said that they would like to keep using this technique in their classes within the next English levels.

b) English Teachers' perceptions about the visual aid (wh-word hand)

The English teachers involved in this study carried out at the Languages Center Universidad Técnica de Ambato, perceived applying visual aids as something truly important. It was also interesting to see students' reactions when using highlighters, colored pencils, graphics and drawings. All the process motivated students to fulfill complex tasks such as: reading and answering questions, identifying main ideas in a text, finding the meaning of new words in a text passage, summarizing information in a mind map, among others. In Addition, students kept focused on the task and answered questions without difficulty. They highlighted the auxiliary with different colored pencil and they knew immediately the tense they had to use to answer the given questions. What is notable is that English teachers perceived that at the beginning it took some time for students to learn whwords. They started questioning every week with one different Wh-word. They used the Wh-word in different contexts. After the midterm examination, students learned to use these wh-question words: what, who, when, where, why, how, how often, how old, how long and which. English teachers did not have to translate the wh-word every time students found one of this in a reading task. At the end, students had a better understanding in pair work discussion, they were able to ask and answer questions without writing them down or looking at the visual aid. 
On the whole, visual aids were found beneficial in the EFL classroom. Also, the on-line survey, and interviews confirmed that A1 and A2 learners benefited from this tool since language learners need to be good at questioning from the beginning of their learning process.

\section{References.}

- Gilakjani, A. P. (2011). Visual, auditory, kinaesthetic learning styles and their impacts on English language teaching. Journal of Studies in Education, 2(1), 104113.

- Carney, R. N., Levin, M. E., \& Levin, J. R. , (1993) Mnemonic strategies: Instructional techniques worth remembering. Teaching Except. Child, 25(4): 24-30.

- Celce-Marcia, M. (2001). Teaching English as a second or foreign language, (3rd ed.). Dewey Publishing Services: NY.

- Chaudron, C. (1988). Second Language Classrooms: Research on Teaching and Learning. New York: Cambridge university Press.

- $\quad$ Dunn, R., \& Dunn, K. (1978). Teaching Students through their Individual Learning Styles. A Practical Approach. Prentice Hall, Reston, VA., ISBN: 10: 0879098082, 336.

- Raiyn, J. (2016). The Role of Visual Learning in Improving Students' High-Order Thinking Skills. Journal of Education and Practice, 7(24), 115-121.

- Kouyoumdjian, H. (2012). Learning Through Visuals. Obtenido de Psychology today: https:www.psychologytoday.com/blog/get-psyched/201207/learningthrough-visuals

- McDaniel, M. A., \& Einstein, G. O. (1986). Bizarre imagery as an effective memory aid: The importance of distinctiveness. Journal of Experimental Psychology: Learning, Memory, and Cognition, 12(1), 54-65.

- Williams, R, (2009). Visual Learning Theory. http: //www.aweoregon.org/research_theory.html.

- Wiyaka, Januarius Mujiyanto, Dwi Rukmini.,. (2018). Students' Perception on the Usefulness of ICT-Based Language Program . Obtenido de http://www.ccsenet.org/journal/index.php/elt/article/view/72882

- Zahedi, Y., \& Abdi, M. (2012). The impact of imagery strategy on EFL learners' vocabulary learning. Procedia-Social and Behavioral Sciences, 69, 2264-2272.

- Web Center for Social Research Methods, (2017). Descriptive Statistics. https://www.socialresearchmethods.net/kb/statdesc.php

- TED. (2011). Melanie West: Visual and auditory learning-how to teach it (video file). Retrieved from https://www.youtube.com/watch?v=KyAaxHvUGog 


\section{Para citar el artículo indexado.}

Hernández E. \& Galora N., (2018). Students' perceptions of visual aids in the EFL classroom. Revista electrónica Ciencia Digital 2(1), 458-472. Recuperado desde: http://www.cienciadigital.org/revistascienciadigital2/index.php/CienciaDigital/article/view/ $\underline{31 / 31}$

\section{LCiencia}

El artículo que se publica es de exclusiva responsabilidad de los autores y no necesariamente reflejan el pensamiento de la Revista Ciencia Digital.

El articulo queda en propiedad de la revista y, por tanto, su publicación parcial y/o total en otro medio tiene que ser autorizado por el director de la Revista Ciencia Digital.
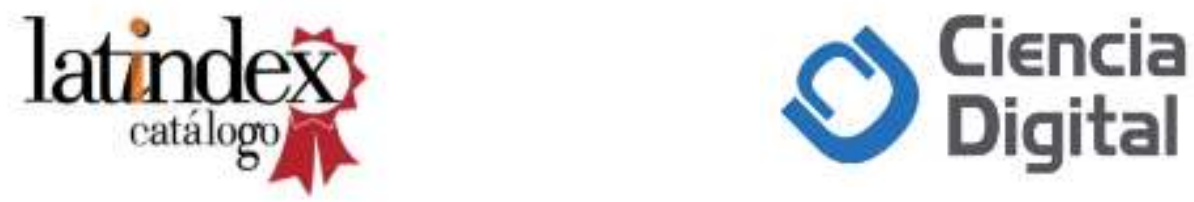